\title{
Effect of soil waterlogging on below- ground biomass allometric relations in Norway spruce
}

Article

Accepted Version

Konopka, B., Moravcik, M., Pajtok, J. and Lukac, M. (2010) Effect of soil waterlogging on below-ground biomass allometric relations in Norway spruce. Plant Biosystems, 144 (2). pp. 448-457. ISSN 1126-3504 doi:

https://doi.org/10.1080/11263501003726391 Available at https://centaur.reading.ac.uk/18383/

It is advisable to refer to the publisher's version if you intend to cite from the work. See Guidance on citing.

To link to this article DOI: http://dx.doi.org/10.1080/11263501003726391

Publisher: Taylor \& Francis

All outputs in CentAUR are protected by Intellectual Property Rights law, including copyright law. Copyright and IPR is retained by the creators or other copyright holders. Terms and conditions for use of this material are defined in the End User Agreement.

www.reading.ac.uk/centaur 
Central Archive at the University of Reading

Reading's research outputs online 


\section{Cover page}

2 Running title:

3 Soil conditions affect belowground allocation in trees

4

5 Corresponding author:

6 Martin Lukac

$7 \quad$ NERC Centre for Population Biology

8 Division of Biology

9 Imperial College London

10 Silwood Park Campus

11 Ascot

12 SL5 7PY

13 UK

14

15

Tel. +44 2075942482

$16 \quad$ Fax +44 1344873173

17 Email:m.lukac@imperial.ac.uk

18 


\title{
Belowground allometric relations in Norway spruce are affected by
} soil waterlogging.

\author{
Bohdan Konôpka ${ }^{1}$, Jozef Pajtík ${ }^{1}$, Martin Lukac ${ }^{2}$ \\ ${ }^{I}$ National Forest Centre, Forest Research Institute Zvolen, T.G. Masaryka 22, 96001 \\ Zvolen, Slovak Republic. \\ ${ }^{2}$ NERC Centre for Population Biology, Division of Biology, Imperial College London, \\ Silwood Park Campus, Ascot, SL5 7PY, UK.
}

\begin{abstract}
An increasing importance is assigned to the estimation and verification of carbon stocks in forests. Forestry practice has several long-established and reliable methods for the assessment of aboveground biomass; however we still miss accurate predictors of belowground biomass. A major windthrow event exposing the coarse root systems of Norway spruce trees allowed us to assess the effects of contrasting soil stone and water content on belowground allocation. Increasing stone content decreases root/shoot ratio, while soil waterlogging leads to an increase in this ratio. We constructed allometric relationships for belowground biomass prediction and were able to show that only soil waterlogging significantly impacts model parameters. We showed that diameter at breast height is a reliable predictor of belowground biomass and, once site-specific parameters have been developed, it is possible to accurately estimate belowground biomass in Norway spruce.
\end{abstract}

Key words: belowground stump, coarse roots, Picea abies, soil stoniness, waterlogging 


\section{Introduction}

In terms of quantitative estimations of tree compartments, substantial interest of forestry research and practice was traditionally paid to the stem and its taper because of the importance of timber production (KozLOWSKI \& PALLARDY, 1997). Alongside the wood producers' interest in timber, tree physiologists and forest ecologists were interested in branches and mainly foliage (KonôPKA et al., 2000). Thus, while aboveground parts of trees have often been surveyed, information on below-ground compartments is less abundant. Lack of quantitative and qualitative parameters describing tree root systems has been mainly caused by the enormous time and labor demands involved in their excavation and, to some extent, an underrating of their significance (DANJON \& REUBENS, 2008).

The root systems are important for tree anchorage, water and nutrients absorption from the soil, as a location for storing carbohydrate reserves and synthesizing growth hormones (KOZLOWSKI \& PALLARDY, 1997). To ensuring all above-mentioned functions, trees must transfer a considerable proportion of assimilated carbohydrates into the root systems. As BRUNNER AND GODBOLD (2007) pointed out, estimation and modeling of belowground structures of trees and forests is particularly important for the calculation of carbon stock and its changes, as well as for understanding and predicting ecosystem functioning.

To avoid arduous work related to the excavation of root system, allometric relations based predominantly on diameter at breast height $(\mathrm{DBH})$ or biomass expansion factors based on stem volume have been used by a number of authors (GREEN et al., 2007; WIRTH et al., 2004; ZIANIS et al., 2005). KRANKINA AND HARMON (1995), LAiHo AND PRESCOTt (1999) and TOBIN et al. (2007a) all provide 
examples of cases where this approach was used for the calculation of belowground necromass as part for carbon stock calculations. The fundamental issue when using these equation and factors is whether such species-specific models constructed for trees grown under particular conditions are applicable for individuals existing in different climate and soils (TOBIN et al., 2007b). For instance, Bolte (2004) in their study concluded that the relationship between $\mathrm{DBH}$ and coarse root biomass was significantly modified by climatic and soil conditions, but less strongly in Norway spruce (Picea abies) than in European beech (Fagus sylvatica) stands.

SCHMIDT-VoGT (1977) wrote that the development of Norway spruce root system appeared to be optimal on deeply developed soils of coarse to medium textures, the species was also well adapted to grow on rock debris, as well as in the neighborhood of raised bogs in the uplands. Thus, a relatively large range of soil conditions may modify Norway spruce root system formation and growth. Several root system types can be determined and classified according to the root system architecture (KÖSTLER et al., 1968). Norway spruce has often been categorised as a "surface-rooter" (STRASBURGER, 1983) or having a "plate-like" root system (STOKES et al., 2007). This rooting habit is thought to be involved in stability and resistance weaknesses of Norway spruce in comparison with other species (e.g. vulnerability to windthrow, drought). For instance, KONÔPKA AND ŽILINEC (1999) compared root systems of Norway spruce and silver fir, two conifer species with very similar aboveground compartment allocation. While the root proportions of these two species in dystric cambisol did not differ, the maximum rooting depth was significantly larger in fir. On the other hand, PUHE (2003) in his review argues that several studies confirm no particular disadvantage of Norway spruce in terms of stability in respect to other tree species. Vertical root distribution of spruce can be considerably modified by inter- 
specific competition with beech (SCHMID \& KAZDA, 2002), but has been shown not to change in the presence of other tree species (KALLIOKOSKI, 2009).

Many studies investigate changes of the root/shoot ratio, considering it the simplest indicator of the relative biomass allocation between below- and aboveground compartments. A decrease of the ratio is generally associated with increasing soil moisture (KRAMER \& KOZLOWSKI, 1979) and with increasing soil fertility (WARING \& SCHLESINGER, 1985). On the other hand, the ratio tends to increase in stress conditions (PUHE, 2003). There is a considerable knowledge concerning shoot and root growth under contrasting soil moisture and nutrient levels, but the knowledge on biomass allocation in soils with varying stoniness (stones and boulders) content are rare. Similarly, comparative studies between tree stands grown on well-drained and water-logged sites are lacking at the present. Very often, soil stoniness and contrasting soil water conditions are omitted in tree biomass partitioning models (see for instance (BARTELINK, 1998).

To address the lack of information in this area, we utilized a major windthrow event which took place in the Tatra Mountains (Slovakia) on $19^{\text {th }}$ November 2004, exposing a large amount of Norway spruce coarse root systems. The objectives of this study were: (1) to construct allometric relationships between stem parameters and below-ground compartment mass of Norway spruce and (2) to evaluate the effects of soil conditions, particularly soil stone content and water-logging, on the relative size of stem, stump and roots as well as on vertical coarse root distribution

\section{Materials and methods}

\section{Locations and sites}


All measurements were conducted in four uneven-aged Norway spruce stands in the High Tatra Mountains (northern Slovakia). The altitude of the stands ranged between 897 and $1171 \mathrm{~m}$ above sea level. The climate is characterised by low average temperatures (annual mean of $5.8{ }^{\circ} \mathrm{C}$ ) and ample precipitation $(750 \mathrm{~mm}$ annually). Mean January temperature is $-5.0{ }^{\circ} \mathrm{C}$ and the snow cover lasts approximately 114 days a year, while the summers are relatively mild with the mean of $14.7^{\circ} \mathrm{C}$ in July (data are from the nearest meteorological station in Stara Lesna, 49 $09^{\prime} \mathrm{N}, 20^{\circ} 17^{\prime} \mathrm{E}$ ). The prevailing bedrock is granodiorite.

We selected plots with decreasing stoniness: Koprova dolina (stand 1; coordinates: $49^{\circ} 09^{\prime} 20^{\prime \prime} \mathrm{N}, 1^{\circ} 57^{\prime} 58^{\prime \prime} \mathrm{E}$ ), Nad Podbanskym (stand 2; coordinates: 49 $08^{\prime} 24^{\prime \prime} \mathrm{N}$, $19^{\circ} 55^{\prime} 47^{\prime \prime}$ E ), Horny Smokovec (stand 3; coordinates: 490 08' 40" N, 20 14' 30" E ). In addition, we included another stand of similar stoniness to stand 2, but with different water regime: Kezmarske zlaby (stand 4; coordinates: 49 $11^{\prime} 32^{\prime \prime} \mathrm{N}, 20^{\circ} 18^{\prime}$ 14" E). Soil stoniness was estimated by exposing and describing five soil profiles at each study plot according to (FAO, 1998). Average stoniness of the whole profile was estimated, rather than that of each horizon, since soil stone content is fairly well distributed due to the post-glacial origin of these soils. The soil of stand 4 was considered different from the other stands due to the presence of a stagnic horizon, suggesting water saturation for long periods. The main soil characteristics of all stands are shown in Table 1.

The stand ages were: Koprova dolina - 107 years, Nad Podbanskym - 65 years, Horny Smokovec - 60 years, Kezmarske zlaby - 53 years. All selected stands were partly damaged by the windstorm of 19th November, 2004. The highest intensity of wind damage was recorded within the stand Kezmarske zlaby with approximately $90 \%$ of individuals heavily damaged, while the lowest intensity was recorded in stand 
Koprova dolina approx. 35\%. All stands originated as either planted or naturally regenerated clumps of spruce trees, which was therefore the dominant species in the canopy of all stands.

\section{Sampling and measurements}

During the summer of 2005, a total of 47 wind-uprooted spruce trees were randomly selected for stem and belowground compartment measurements. First, the branches were cut from the stem and the tree height was measured using a tape. Diameter measurements using calipers (two diameters perpendicular to one another) were taken from all sampled trees at the following positions: tree base (ground level, D0H), 20 $(\mathrm{D} 20 \mathrm{H})$ and $130 \mathrm{~cm}(\mathrm{DBH})$ from the base, and also every $100 \mathrm{~cm}$ from the base to the top of the tree. A summary of measured stem parameters can be found in Table 2 .

The position of the ground level was identified on each stem and the trees were then cut and separated into above- and belowground parts. Soil and stones still attached to the root systems exposed by windthrow were cleaned with the help of spades, picks and chisels. The original depth allocation of $0-30 \mathrm{~cm}, 30-60 \mathrm{~cm}$ and over $60 \mathrm{~cm}$ was marked out on all the roots. The exposed root plate were undisturbed by the windthrow, enabling a fairly accurate estimation of original root depth. Broken roots still in the soil were paired up with fresh root injuries on the exposed part of the root system, excavated manually and tagged. All roots under the diameter of $1 \mathrm{~cm}$ were cut off by secateurs and disposed of. Then, roots in each depth category were separated from the stump cylinder and classified into the following diameter classes: $1.0-2.5 \mathrm{~cm}, 2.6-5.0 \mathrm{~cm}, 5.1-7.5 \mathrm{~cm}$ and so on until the maximum diameter of $30 \mathrm{~cm}$. All of these observations were carried out on the exposed half of the root system, created by an imaginary horizontal plane drawn through the centre of the stump. As 
the trees were mostly uprooted by northern, north-western and western wind, measured halves of the roots systems were always oriented to the north and the west of each stump. The prevailing wind direction and the direction of the windthrow were identical in all four compared stands, thus minimizing the error due to uneven root system development (DANJON et al., 2005; TAMASI et al., 2005).

At this point it is important to mention the existing inconsistency in terms of terminology and non-uniform specification of root system segments existing in the literature (TOBIN et al., 2007a). The term "belowground biomass" is generally well defined and used to identify the belowground part of the stump and all roots. On the other hand, the meaning of "roots" and especially "root system" is not always uniform in the literature because of a facultative consideration of the stump. Definition of "coarse roots" is also not consistent, since different authors specify various diameters as the threshold between fine and coarse roots. The values most often used are $0.2 \mathrm{~cm}$ (e.g. BOLTE et al. (2004), $0.5 \mathrm{~cm}$ (e.g CURIEL YUSTE (2004) or $1.0 \mathrm{~cm}$ (e.g. FINER et al. (1997). In this paper, the term "below-ground biomass" is used to describe the belowground part of the stump plus coarse roots with a minimum diameter of $1.0 \mathrm{~cm}$.

A measurement of the diameter and length of all root segments was taken as they were removed from each depth class $(0-30,30-60$ and $60+\mathrm{cm})$. The diameter of the belowground portion of the stump was established at its top, middle and bottom. The volume of all root and stem segments was then calculated according to an equation for a frustum of a cone:

$$
\mathrm{V}=\pi / 3 * 1 *\left(\mathrm{r}_{1}{ }^{2}+\mathrm{r}_{1} * \mathrm{r}_{2}+\mathrm{r}_{2}{ }^{2}\right)
$$

$$
\text { where: }
$$

$$
1 \text { - root or stem segment length }
$$$$
\mathrm{r}-\text { root or stem radius at the top }\left(\mathrm{r}_{1}\right) \text { and bottom }\left(\mathrm{r}_{2}\right) \text { end of a segment. }
$$ 
The total volume of stems and roots was then calculated by summing up the

volumes of all stem and root segments. The volume of the below-ground portion of the stump was expressed by Newton's formula:

$$
\mathrm{V}=\pi * 1 *\left(\mathrm{r}_{1}^{2}+\mathrm{r}_{2}^{2}+4 \mathrm{r}_{3}^{2}\right) / 6
$$

where:

$$
\begin{aligned}
& \mathrm{l} \text { - stump length } \\
& \mathrm{r} \text { - stump radius in top }\left(\mathrm{r}_{1}\right) \text {, bottom }\left(\mathrm{r}_{2}\right) \text { and middle }\left(\mathrm{r}_{3}\right) \text { part of the stump. }
\end{aligned}
$$

\section{Biomass equations}

We tested two equations in order to develop a suitable model for belowground biomass prediction, and to test whether site conditions alter the model parameters. First, equation (3), presented by FINER (1989) and LAIHO AND FINER (1996) among others, was used with $\mathrm{D} 20 \mathrm{H}$ and $\mathrm{DBH}$ to predict coarse root and total belowground biomass of spruce trees at every site.

$$
\text { Biomass }=\mathrm{B} 1 * \mathrm{X}^{\mathrm{B} 2}
$$

Subsequently, an equation (4) recently introduced by PETERSSON AND STAHL (2006) was tested for goodness of fit with D20H and DBH. This equation is meant to take into account the fact that root biomass is not zero when DBH or D20H have zero value.

$$
\text { Biomass }=\mathrm{e}^{(\mathrm{B} 0+\mathrm{B} 1 * \mathrm{X})}
$$

Stem height and stem volume were also tested for their fitness as predictors of belowground biomass, a range of functions was tested including linear, exponential and polynomial equations.

\section{Analysis and statistics}

We constructed separate models for belowground biomass prediction for each stand. Resulting coefficients were then compared using extra sum-of-squares $F$ test to test 
for influence of soil conditions on belowground biomass prediction. Model fitting and statistical comparisons were done in SigmaStat 3.0 (Systat, California, USA) and GraphPad Prism 5 (GraphPad Software Inc., USA). All significances are reported at $P<0.05$.

\section{Results}

Initial comparison of measured stem characteristics revealed that stand 1 (Koprova dolina) was different from all other stands. This was the case for diameter at $20 \mathrm{~cm}$ $(P<0.002)$ DBH $(P<0.002)$, stem height $(P<0.007)$ and stem volume $(P<0.001)$. The remaining three stands did not differ in any of these parameters (Table 2). Similarly, belowground biomass was higher in Koprova dolina compared to the other three locations $(P<0.003)$. The root/shoot ratio of sampled trees was also affected by the site conditions, stand 1 having significantly lower root/shoot ratio than stand 3 (Horny Smokovec, $P<0.001)$ and stand 4 (Kezmarske zlaby, $P=0.005$, Figure 1).

Using our observations of above- and belowground biomass we constructed biomass equations linking root and total belowground biomass to aboveground parameters. In general, both $\mathrm{D} 2 \mathrm{OH}$ and $\mathrm{DBH}$ are considered to be reasonably good predictors of coarse root biomass (e.g. ToBIN et al. (2007b). The estimated values of parameters from equations (3) and (4) are detailed in Table 3. Both equations fit the data reasonably well, however equation (3) appears to be more accurate in predicting coarse root and total belowground biomass than equation (4).

To evaluate the effects of soil conditions, particularly soil stoniness and waterlogging on the relationship between aboveground parameters and belowground biomass, we carried out a comparison of models resulting from our observations (Figures 2 and 3). There was no significant difference between the models due to the 
stone content of the soil. Stand 1 (Koprova dolina) was only nearly significantly different from stand 3 (Horny Smokovec) when D20H was used to predict total belowground biomass $(P=0.0650$ and $P=0.0652$ for equations (3) and (4) respectively). However, we observed a very strong effect of soil water logging on model coefficients. The models for stand 4 (Kezmarske zlaby) with very high water table differed from all other stands regardless of which stem diameter or equation was used to predict belowground biomass $(P<0.008)$. For this reason, Table 3 reports the regression coefficients for stands 1, 2 and 3 pooled together and for stand 4 separately.

Since stand 1 (Koprova dolina) was so different from the other three stands, to assess the effect of soil conditions on coarse root and belowground stump biomass we compared the relative sizes of biomass pools. Coarse root/stem biomass ratio was inversely related to the stone content in the soil. Coarse root biomass in the very stony soil of stand 1 did amount to $17 \%$ of stem biomass, while in stand 2 this increased to $23 \%(P=0.056)$ and in least stony stand 3 to $26 \%(P=0.002)$. Similarly, high stone content negatively impacted on the volume of the belowground portion of the stump relative to the stem volume. Stand 3 had the highest ratio of $10 \%$, significantly different from stand $2(6 \%, P<0.001)$ and stand $1(5 \%, P<0.001)$. The ratio between belowground stump and coarse root volume was also reduced by high stone content $(\mathrm{P}=0.0211)$

When comparing the root depth allocation in stands 1, 2 and 3, we did not observe any difference in the proportion of the root system in the $0-30 \mathrm{~cm}$ soil depth $(P=0.210)$ or $30-60 \mathrm{~cm}$ depth $(P=0.365)$. In the over $60 \mathrm{~cm}$ soil layer, a larger proportion of the root system was found in stand 1 with the highest stone content (Koprova dolina, 16\%) than in stand 3 with the lowest stone content (Horny 
Smokovec, 7\%, $P=0.015$, Figure 4). We did not include stand 4 (Kezmarske zlaby) in this comparison, since $100 \%$ of coarse spruce roots in this water-logged location were found in the $0-30 \mathrm{~cm}$ soil layer.

\section{Discussion}

\section{Soil stoniness}

The results show that a high proportion of boulders decreases the ratio between the belowground root system and the stem (root/shoot ratio), restricts the size of the belowground stump and increases the proportion of roots in the deepest soil horizons. Our results have to be interpreted with caution, mainly because stand 1 is somewhat older than the remaining stands. This should not have a significant influence on our observation, since the root/shoot ratio changes rapidly in young trees, but stabilizes fairly soon and does not change in mature trees (JOHNSON et al., 2003; PAJTIK et al., 2008). Mechanical resistance and limited space within a soil profile with high boulder content do therefore influence biomass partitioning, as well as vertical root distribution in spruce trees. We attribute the increase in the coarse root biomass volume compared to the stump volume to the fact that the roots are more flexible in using the available space between the stones than the stump. Downwardly directed roots can deflect to horizontal growth along the surface of mechanical barriers, but turn back downwards if they encounter a cavity (DEXTER, 1986).

Our field observations also reveal (data not shown) that the stone content interferes with coarse root growth and alters not only the direction of growth, but also induces structural changes, such as root/stump ratio or root branching pattern. Greater presence of boulders in the soil places restrictions on root growth and functioning at depths where they are normally found. In order to explore a sufficient volume of soil, 
spruce root systems in very stony soil had to extend into deeper soil horizons. This observation has potential bearing on the parameterization of biomass-partitioning models, carbohydrate cost of tree root system development and estimates of $\mathrm{C}$ storage in forest soil, a perspective that however still needs to be fully explored. Further studies in stands of comparable age need to be carried out, since it has been shown that vertical distributions of coarse roots may change with stand age (KALLIOKOSKI et al., 2008). Root quantity, vertical distribution and morphological features are likely to be important for water and nutrient acquisition. Reduced root extension can result in low nutrient-uptake and increase susceptibility to water deficiency (PUHE, 2003). CANAdell et al. (1996) in his review pointed out the importance of deep roots, particularly for ecosystem water fluxes, as well as for carbon and nutrient cycling.

\section{Waterlogging}

Waterlogged conditions increased the root/shoot ratio but, at the same time, drastically diminished root system depth and reduced the size of belowground stump relative to the stem. We expect the high value of this indicator to be linked to the limited root depth in the soil and consequently to lower nutrient availability. This view is supported by TOBIN et al. (2007b) who posit that trees growing on wet sites may need larger root systems for oxygen and nutrient uptake, or simply for anchorage. Waterlogged soils are generally characterised by a lack of oxygen and high levels of $\mathrm{CO}_{2}$ and ethylene (ARMSTRONG, 1982), creating conditions which explain decreased rooting depth and the existence of extremely shallow spruce root systems. Superficial root systems in waterlogged soils have been reported by a variety of authors (KonÔPKA, 2002; PYATT, 1966). At our site, spruce coarse root systems consisted of an extremely dense tangle, part of which was formed by root necromass, similar to those reported by COUTTS (1989). He stated that a zone of periodic death 
and re-growth of roots (shaving brush roots) was often established in waterlogged soils since the positive geotropism of downward growing roots is never altered and seasonal fluctuations of water table kill off any new roots. Our results which indicate an increase in root/shoot ratio on a waterlogged soil are also in agreement with those of RAY AND NICOLL (1998), who indicated an increase of root biomass with decreasing total rooting depth. TOBIN et al. (2007b) stated that a positive feedback relationship might exist between root biomass quantity and anchorage; further biomass being required to support more extensively ramifying surface roots.

\section{Allometric relations in contrasting soil conditions}

Using the measurements in the Tatra Mountains, we have constructed allometric relations for belowground biomass prediction. We have compared two models (equation 3 and 4) available in the literature, finding no difference between the models regarding the effects of soil conditions on belowground biomass prediction. Perhaps surprisingly, given the response of biomass allocation ratios to increasing soil stoniness, there was no significant difference between the models fitted to the data from the sites with well-draining soil. All observations from stands 1, 2 and 3 were well captured with just a single model (Table 3). Waterlogging, on the other hand, had a strong impact on the model parameters, suggesting that it is this soil condition that has to be considered when constructing generalized belowground biomass allometric relations. Allometric relations are often thought to be modified by climatic or soil conditions (BOLTE et al., 2004; WIRTH et al., 2004). In our case, waterlogging did increase the belowground biomass relative to the stem.

Both stem diameters measured in this study, 20 and $130 \mathrm{~cm}$ above ground level (D20H and DBH, respectively), proved to be suitable parameters for estimates of belowground biomass. However, at the waterlogged site, we observed the formation 
of large buttresses (as evidenced by the largest base shape ratio at this site, Table 2). Since the depth penetration of the stump was severely limited at this site, larger buttresses have probably developed to aid stability and resulted in uneven thickening of the stem base. As a result, cross-sections of stem bases at this site were irregular, resulting in higher variability of $\mathrm{D} 20 \mathrm{H}$ values in comparison to $\mathrm{DBH}$. Model fits based on DBH show higher coefficient of determination than those based on D20H at the waterlogged site (such differences were less clear in the other sites). Thus, DBH should be preferred to $\mathrm{D} 2 \mathrm{OH}$ as a predictor of belowground biomass at waterlogged sites.

\section{Soil conditions and tree anchorage}

There are several important aspects worth considering in terms of tree resistance to uprooting and stand stability. Stokes (2002) stated that tree anchorage is mainly affected by root/shoot ratio, vertical root distribution, radial symmetry, as well as the spread and the shape of lateral roots, the latter demonstrated by NICOLL AND RAY (1996) and RuEL et al. (2003). Coutts (1989) noted that roots could be categorised into three principal groups: taproots, lateral roots and sinkers. Taproots, and especially sinkers, are believed to be the most important for anchoring (DANJON et al., 2005), while the proportions of the particular type of roots can be considerably modified due to mechanical barriers or water-logging.

Theoretically, tree anchorage should improve with higher values of root/shoot (alternatively root/stem) ratio, root/belowground biomass ratio (discriminating the stump which is less important for tree anchorage than roots) and especially with increasing proportion of roots in deeper soil layers. However, it seems that for accurate evaluation of tree anchorage, the root system parameters must be combined with the soil property data (see also DUPUY et al. (2005). For instance, high root/shoot 
ratio and high root/belowground biomass ratio could indicate good spruce anchorage at our waterlogged site. However, the stand at this site was completely uprooted by the windstorm. RoTTMANN (1989) stated that waterlogging worsens the coherence of soil and the root-soil friction, a confluence of which drastically lowers root anchorage. At the other extreme, low root/shoot ratio at our boulder site, on its own, would indicate low tree anchorage. However, a large part of this stand was left undamaged, many trees were broken at the stem rather than uprooted. We assume that the roots ingrown between stones were difficult to pull out from the soil and consequently did reinforce anchorage.

\section{Conclusion}

A severe windthrow event in forests dominated by Norway spruce has allowed us to assess the effect of soil conditions on coarse root and belowground stump biomass allocation. Increasing stone content of the soil had a negative influence on root/shoot ratio, while soil waterlogging resulted in the predomination of roots at the expense of shoots. We have shown that it is possible to construct reliable models predicting belowground biomass. DBH proved to be a stable and accurate predictor variable, across all site and soil conditions, however model coefficients have to be site specific, especially if they are to be applied to sites with contrasting soil water conditions.

\section{Acknowledgements}

We thank prof. Jozef Konôpka for helping with the plot selection and experimental design and Dr. Brian Tobin for comments on the manuscript. We acknowledge Mr. Miroslav Lipnický and Ondrej Kolenič for technical and logistic assistance. This research was supported by the Slovak Research and Development Agency 
395 ("Vulnerability of forest ecosystems destabilized by wind to the impact of some 396 disturbance factors" APVV-0612-07 project). 


\section{References}

ARMSTRONG W. 1982 - Water logged soil. In Environment and plant ecology. Ed. J.R. ETHRINGTON. Jhon Wiley, Chichester

BARTELINK H.H. 1998 - A model of dry matter partitioning in trees. Tree Physiol 18: 91-101.

Bolte A., Rahmann T., Kuhr M., Pogoda P., Murach D. \& Von Gadow K. 2004 - Relationships between tree dimension and coarse root biomass in mixed stands of European beech (Fagus sylvatica L.) and Norway spruce (Picea abies [L.] Karst.). Plant Soil 264: 1-11.

Canadell J., Jackson R.B., Ehleringer J.R., Mooney H.A., SAla O.E. \& Schulze E.D. 1996 Maximum rooting depth of vegetation types at the global scale. Oecologia 108: 583-595.

CARney K.M., Hungate B.A., DraKe B.G. \& Megonigal J.P. 2007 - Altered soil microbial community at elevated CO2 leads to loss of soil carbon. Proceedings of the National Academy of Sciences of the United States of America 104: 4990-4995.

CoutTs M.P. 1989 - Factors Affecting the Direction of Growth of Tree Roots. Ann Sci Forest 46: S277-S287.

CURIEl Yuste J., JANSSENS I.A., CARRARA A. \& CEUlEMANS R. 2004 - Annual $Q_{10}$ of soil respiration reflects plant phenological patterns as well as temperature sensitivity. Global Change Biology 10: 161-169.

DANJON F., FOURCAUD T. \& BERT D. 2005 - Root architecture and wind-firmness of mature Pinus pinaster. New Phytologist 168: 387-400.

DANJON F. \& REUBENS B. 2008 - Assessing and analyzing 3D architecture of woody root systems, a review of methods and applications in tree and soil stability, resource acquisition and allocation. Plant Soil 303: 1-34.

DEXTER A.R. 1986 - Model experiments on the behavior of roots at the interface between a tilled seedbed and a compacted subsoil.1. Effects of seed-bed aggregate size and subsoil strength on wheat roots. Plant Soil 95: 123-133.

DUPUY L., FOURCAUD T. \& STOKES A. 2005 - A numerical investigation into the influence of soil type and root architecture on tree anchorage. Plant Soil 278: 119-134.

FAO 1998 - World Reference Base for Soil Resources. World Soil Resources Report. No. 84. ISSISRIC-FAO, Rome.

FINER L. 1989 - Biomass and nutrient cycle in fertilized and unfertilized pine, mixed birch and pine and spruce stands on a drained mire. Acta Forestalia Fennica 208: 1-63.

FINER L., MESSIER C. \& DEGRANDPRE L. 1997 - Fine-root dynamics in mixed boreal conifer-broadleafed forest stands at different successional stages after fire. Can J Forest Res 27: 304-314.

GREen C., TOBIN B., O'ShEA M., FARRELl E.P. \& BYRNE K.A. 2007 - Above- and belowground biomass measurements in an unthinned stand of Sitka spruce (Picea sitchensis (Bong) Carr.). Eur J Forest Res 126: 179-188.

Johnson D.W., Hungate B.A., Dijkstra P., Hymus G., Hinkle C.R., Stiling P. \& DraKe B.G. 2003 - The effects of elevated CO2 on nutrient distribution in a fire-adapted scrub oak forest. Ecological Applications 13: 1388-1399.

KALLIOKOSKI T. 2009 - Tree roots as self-similar branching structures: axis differentiation and segment tapering in coarse roots of three boreal forest tree species. Trees-Struct Funct: DOI: 10.1007/s00468-00009-00393-00461.

KALliokoski T., NyGREn P. \& SiEVANEN R. 2008 - Coarse root architecture of three boreal tree species growing in mixed stands. Silva Fennica 42: 189-210.

KONÔPKA B. 2002 - Relationship between parameters of the aboveground parts and root system in norway spruce with respect to soil drainage. Ekol Bratislava 21: 155-165.

KonÔPKA B., TSUKHARA H. \& NETSU A. 2000 - Biomass distribution in 40-year-old trees of Japanese black pine. J Forest Res-Jpn 5: 163-168.

KONÔPKA B. \& ŽILINEC M. 1999 - Aboveground and belowground biomass comparison between Norway spruce (Picea abies (L.) Karst.) and silver fir (Abies alba Mill.) in a mixed fir-spruce stand. Ekol Bratislava 18: 154-161.

KÖSTLER J.N., BRÜCKNER E. \& BIBELRIETHER E. 1968 - Die Wurzeln der Waldbäume. Verlag Paul Parey, Hamburg.

Kozlowski T.T. \& PAllardy S.G. 1997 - Physiology of woody plants. Academic Press, San Diego.

KrAMER P.J. \& KozlowsKi T.T. 1979 - Physiology of trees. McGraw-Hill, New York,. 
KRANKINA O.N. \& HARMON M.E. 1995 - Dynamics of the dead wood carbon pool in northwestern Russian boreal forests. Water Air and Soil Pollution 82: 227-238.

LAIHO R. \& FINER L. 1996 - Changes in root biomass after water-level drawdown on pine mires in southern Finland. Scand J Forest Res 11: 251-260.

LAIHO R. \& PRESCOTT C.E. 1999 - The contribution of coarse woody debris to carbon, nitrogen, and phosphorus cycles in three Rocky Mountain coniferous forests. Can J Forest Res 29: 15921603.

NICOLL B.C. \& RAY D. 1996 - Adaptive growth of tree root systems in response to wind action and site conditions. Tree Physiol 16: 891-898.

PAJTIK J., KONOPKA B. \& LUKAC M. 2008 - Biomass functions and expansion factors in young Norway spruce (Picea abies [L.] Karst) trees. Forest Ecol Manag 256: 1096-1103.

Petersson H. \& StAHL G. 2006 - Functions for below-ground biomass of Pinus sylvestris, Picea abies, Betula pendula and Betula publescens in Sweden. Scand J Forest Res 21: 84-93.

PUHE J. 2003 - Growth and development of the root system of Norway spruce (Picea abies) in forest stands - a review. Forest Ecol Manag 175: 253-273.

PyATT D.G. 1966 - The soil and windthrow surveys of Newcastleton Forest. Roxburghshire Scottish Forestry 20: 175-183.

RAY D. \& NICOLL B.C. 1998 - The effect of soil water-table depth on root-plate development and stability of Sitka spruce. Forestry 71: 169-182.

RotTmann M. 1989 - Wind- und Sturmschäden im Wald. J. D. Sauerländers Verlag, Dransfeld.

RUEL J.C., LAROUCHE C. \& ACHIM A. 2003 - Changes in root morphology after precommercial thinning in balsam fir stands. Can J Forest Res 33: 2452-2459.

SCHMID I. \& KAZDA M. 2002 - Root distribution of Norway spruce in monospecific and mixed stands on different soils. Forest Ecol Manag 159: 37-47.

SchmidT-VoGT H. 1977 - Die Fichte. Bd. 1: Taxonomie, Verbreitung, Morphologie, Ökologie, Waldgesellschaften. Verlag Paul Parey, Hamburg.

STOKES A. 2002 - Biomechanics of tree root anchorage. In Plant roots: The hidden half. Eds. Y. WAISEL, A. ESHEL \& U. KAFKAKI. Marcel Dekker Inc, New York

Stokes A., AbdGhani M., Salin F., Danjon F., Jeannin H., Berthier S., KoKutse A. \& Frochot H. 2007 - Root morphology and strain distribution during tree failure on mountain slopes. In Eco- and ground bio-engineering: the use of vegetation to improve slope stability. Developments in plant and soil sciences. Eds. A. STOKES, I. SPANOS, J.E. NORRIS \& L.H. CAMMERAAT. Springer, Dordrecht

STRASBURGER E. 1983 - Lehrbuch der Botanik. Gustav Fischer Verlag, Stuttgart.

TAMAsi E., StOKes A., LASSERre B., DANJON F., Berthier S., FourCAud T. \& ChiATANTE D. 2005 Influence of wind loading on root system development and architecture in oak (Quercus robur L.) seedlings. Trees-Struct Funct 19: 374-384.

TOBIn B., BLACK K., MCGURDY L. \& NIEUWENHUIS M. 2007a - Estimates of decay rates of components of coarse woody debris in thinned Sitka spruce forests. Forestry 80: 455-469.

Tobin B., ČERMÁK J., Chiatante D., DAnjon F., A. D.I., Dupuy L., Eshel A., Jourdan C., Kalliokoski T., Laiho R., Nadezhdina N., Nicoll B., Pagès L., Silva J. \& Spanos I. 2007b - Towards developmental modeling of tree root systems. Plant Biosystems 141: 481501.

WARING R.H. \& SCHLESINGER W.H. 1985 - Forest Ecosystem: Concepts and Management. Academic Press, Orlando, Florida.

WIRTH C., SCHUMACHER J. \& SCHULZE E.D. 2004 - Generic biomass functions for Norway spruce in Central Europe - a meta-analysis approach toward prediction and uncertainty estimation. Tree Physiol 24: 121-139.

ZIANIS D., MUUKKONEN P., MÄKIPÄÄ R. \& MENCUCCINI M. 2005 - Biomass and stem volume equations for tree species in Europe. Silva Fennica Monographs. 
Table 1. Soil characteristics of the experimental plots

\begin{tabular}{|c|c|c|c|c|}
\hline $\begin{array}{l}\text { Stand name } \\
\text { and number }\end{array}$ & Soil type & $\begin{array}{l}\text { Type of } \\
\text { stones } \\
\end{array}$ & $\begin{array}{l}\text { Proportion } \\
\text { of stones }^{\#} \\
\end{array}$ & $\begin{array}{l}\text { Water } \\
\text { regime }\end{array}$ \\
\hline Koprova dolina & humic podzol & boulder & $65 \% *$ & well drained \\
\hline Nad Podbanskym (2) & cambic podzol & stony & $45 \% *$ & well drained \\
\hline Horny Smokovec (3) & haplic cambisol & moderate stony & $25 \% *$ & well drained \\
\hline Kezmarske zlaby (4) & stagnic pseudogley & stony & $40 \% * *$ & water-logged \\
\hline
\end{tabular}

Notes: \# - on volumetric base

* - at soil depth $0-100 \mathrm{~cm}$

** - at soil depth 0-30 cm (conforms with maximum rooting depth) 
Table 2. Aboveground parameters of trees selected for root system measurements (D20H denotes stem diameter at $20 \mathrm{~cm}$ from the ground level, DBH is diameter at breast height, i.e. $130 \mathrm{~cm}$ from the ground level).

\begin{tabular}{|c|c|c|c|c|c|c|}
\hline $\begin{array}{l}\text { Stand name and } \\
\text { number }\end{array}$ & $\begin{array}{l}\text { Number } \\
\text { of trees }\end{array}$ & $\begin{array}{l}\text { Height } \\
(\mathrm{cm})[\mathrm{A}]\end{array}$ & $\begin{array}{l}\text { D20H } \\
(\mathrm{cm})[\mathrm{B}]\end{array}$ & $\begin{array}{l}\text { DBH } \\
(\mathbf{c m})[\mathrm{C}]\end{array}$ & $\begin{array}{l}\text { Slenderness } \\
\text { ratio }[\mathrm{A} / \mathrm{C}]\end{array}$ & $\begin{array}{l}\text { Base shape } \\
\text { ratio }[\mathrm{B} / \mathrm{C}]\end{array}$ \\
\hline Koprova dolina & 11 & 2450 & 40.7 & 33.3 & 74 & 1.22 \\
\hline Nad Podbanskym (2) & 10 & 1790 & 25.6 & 20.6 & 87 & 1.24 \\
\hline Horny Smokovec (3) & 12 & 1650 & 22.8 & 19.5 & 85 & 1.17 \\
\hline Kezmarske zlaby & 14 & 1400 & 20.5 & 16.0 & 88 & 1.28 \\
\hline
\end{tabular}


Table 3. Regression coefficients B0, B1, B2, their standard errors (S.E.), p-value (P), degrees of freedom (DF), coefficient of determination ( $\mathrm{R}^{2}$ ), for equations (3) and (4) predicting coarse root and total belowground biomass from DBH and D20H respectively. Stands 1- 3 (Koprova dolina, Nad Podbanskym and Horny Smokovec) were estimated together since their separate model fits were not significantly different.

\begin{tabular}{|c|c|c|c|c|c|c|c|}
\hline Equation & Model & Stands & B0 (SE) $P$ & $\mathrm{~B} 1(\mathrm{SE}) P$ & $\mathrm{~B} 2(\mathrm{SE}) P$ & $\mathrm{DF}$ & $\mathrm{R}^{2}$ \\
\hline \multirow[t]{8}{*}{ (3) } & \multirow{2}{*}{$\mathrm{DBH}$ - Coarse roots } & $1-3$ & & $0.000254(0.0000933) 0.010$ & $1.812(0.101)<0.001$ & 32 & 0.937 \\
\hline & & 4 & & $0.0000316(0.0000401) 0.446$ & $2.638(0.385)<0.001$ & 13 & 0.931 \\
\hline & \multirow{2}{*}{ DBH - Belowground biomass } & $1-3$ & & $0.000258(0.000102) 0.016$ & $1.892(0.108)<0.001$ & 32 & 0.934 \\
\hline & & 4 & & $0.0000349(0.0000353) 0.343$ & $2.657(0.314)<0.001$ & 13 & 0.953 \\
\hline & \multirow{2}{*}{ D20H - Coarse roots } & $1-3$ & & $0.0000615(0.0000393) 0.127$ & $2.105(0.169)<0.001$ & 32 & 0.905 \\
\hline & & 4 & & $0.000207(0.000254) 0.431$ & $1.876(0.341)<0.001$ & 13 & 0.867 \\
\hline & \multirow{2}{*}{ D20H - Belowground biomass } & $1-3$ & & $0.0000486(0.0000337) 0.160$ & $2.247(0.181)<0.001$ & 32 & 0.906 \\
\hline & & 4 & & $0.000225(0.000242) 0.369$ & $1.898(0.298)<0.001$ & 13 & 0.897 \\
\hline \multirow[t]{8}{*}{ (4) } & \multirow{2}{*}{ DBH - Coarse roots } & $1-3$ & $-3.900(0.146)<0.001$ & $0.0557(0.00358)<0.001$ & & 32 & 0.897 \\
\hline & & 4 & $-5.075(0.495)<0.001$ & $0.126(0.0193)<0.001$ & & 13 & 0.901 \\
\hline & \multirow{2}{*}{ DBH - Belowground biomass } & $1-3$ & $-3.668(0.154)<0.001$ & $0.0575(0.00376)<0.001$ & & 32 & 0.896 \\
\hline & & 4 & $-4.938(0.419)<0.001$ & $0.127(0.0164)<0.001$ & & 13 & 0.927 \\
\hline & \multirow{2}{*}{ D20H - Coarse roots } & $1-3$ & $-4.338(0.196)<0.001$ & $0.0579(0.00426)<0.001$ & & 32 & 0.899 \\
\hline & & 4 & $-4.246(0.467)<0.001$ & $0.0677(0.0133)<0.001$ & & 13 & 0.795 \\
\hline & \multirow{2}{*}{ D20H - Belowground biomass } & $1-3$ & $-4.163(0.205)<0.001$ & $0.0608(0.00442)<0.001$ & & 32 & 0.904 \\
\hline & & 4 & $-4.112(0.423)<0.001$ & $0.0685(0.0120)<0.001$ & & 13 & 0.828 \\
\hline
\end{tabular}


Figure 1. Ratio of belowground biomass volume to stem volume in Koprova dolina (1), Nad Podbanskym (2), Horny Smokovec (3) and Kezmarske zlaby (4) [ \pm SE], letters denote significant difference at $P<0.05$.

Figure 2. Coarse root volume and belowground biomass volume prediction curves based on equation (3).

Figure 3. Coarse root volume and belowground biomass volume prediction curves based on equation (4).

Figure 4. Proportion of coarse root volume in different soil depths in Koprova dolina (1), Nad Podbanskym (2) and Horny Smokovec (3) stands [\%], letters denote significant difference at $P<0.05$. 


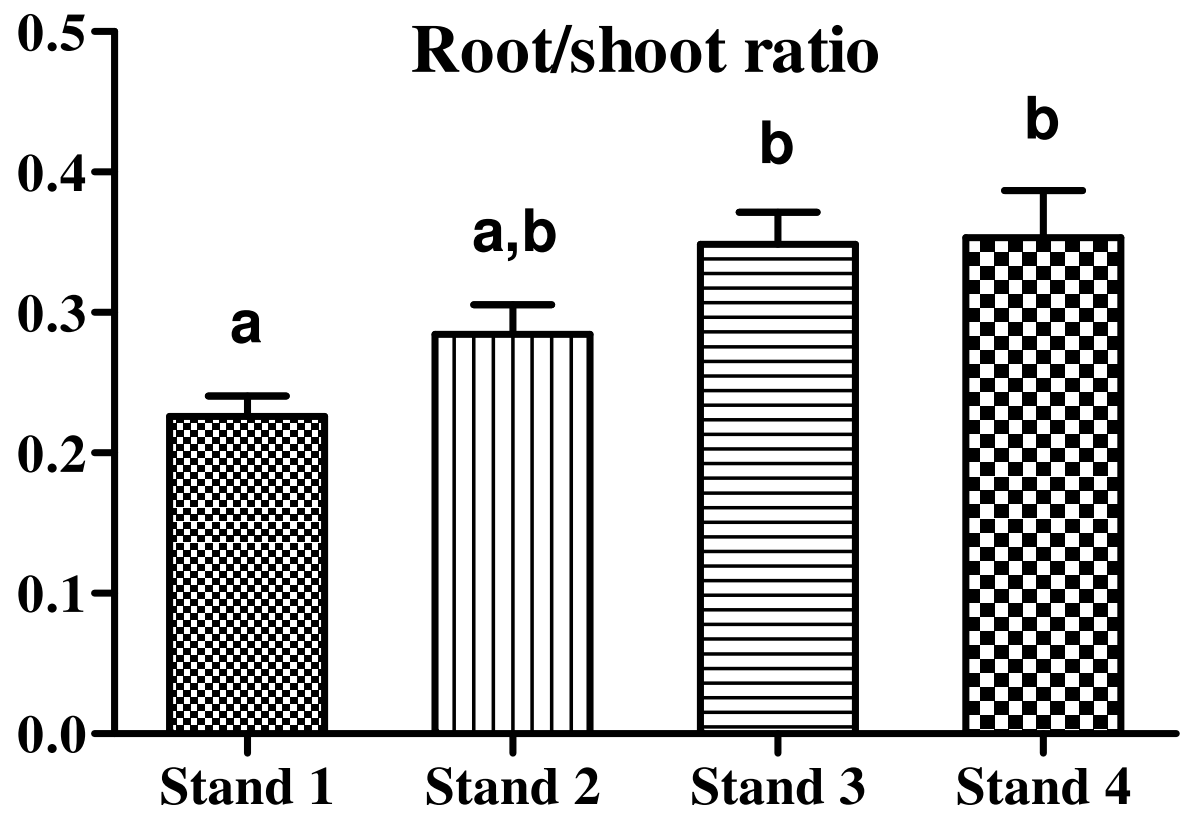



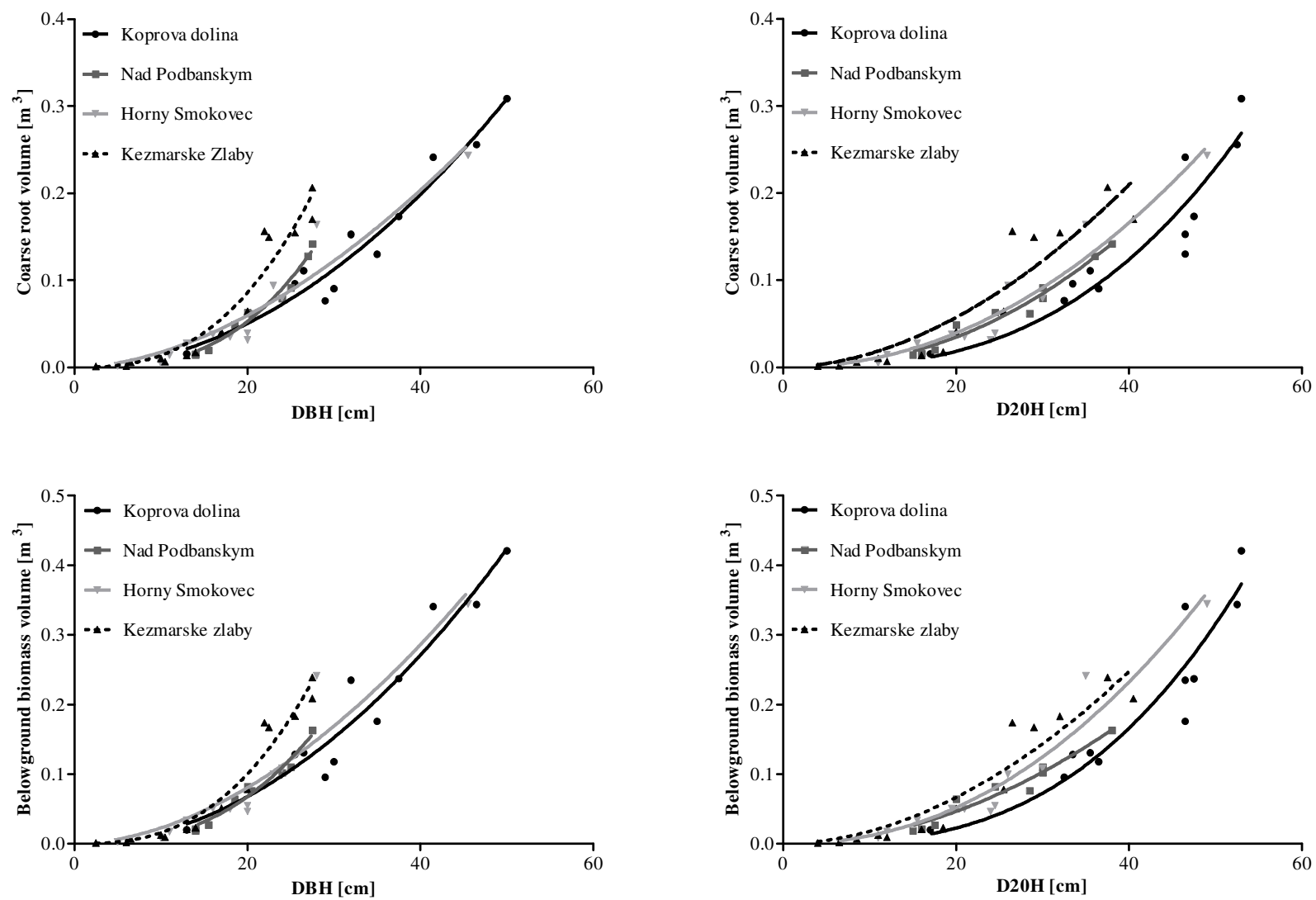

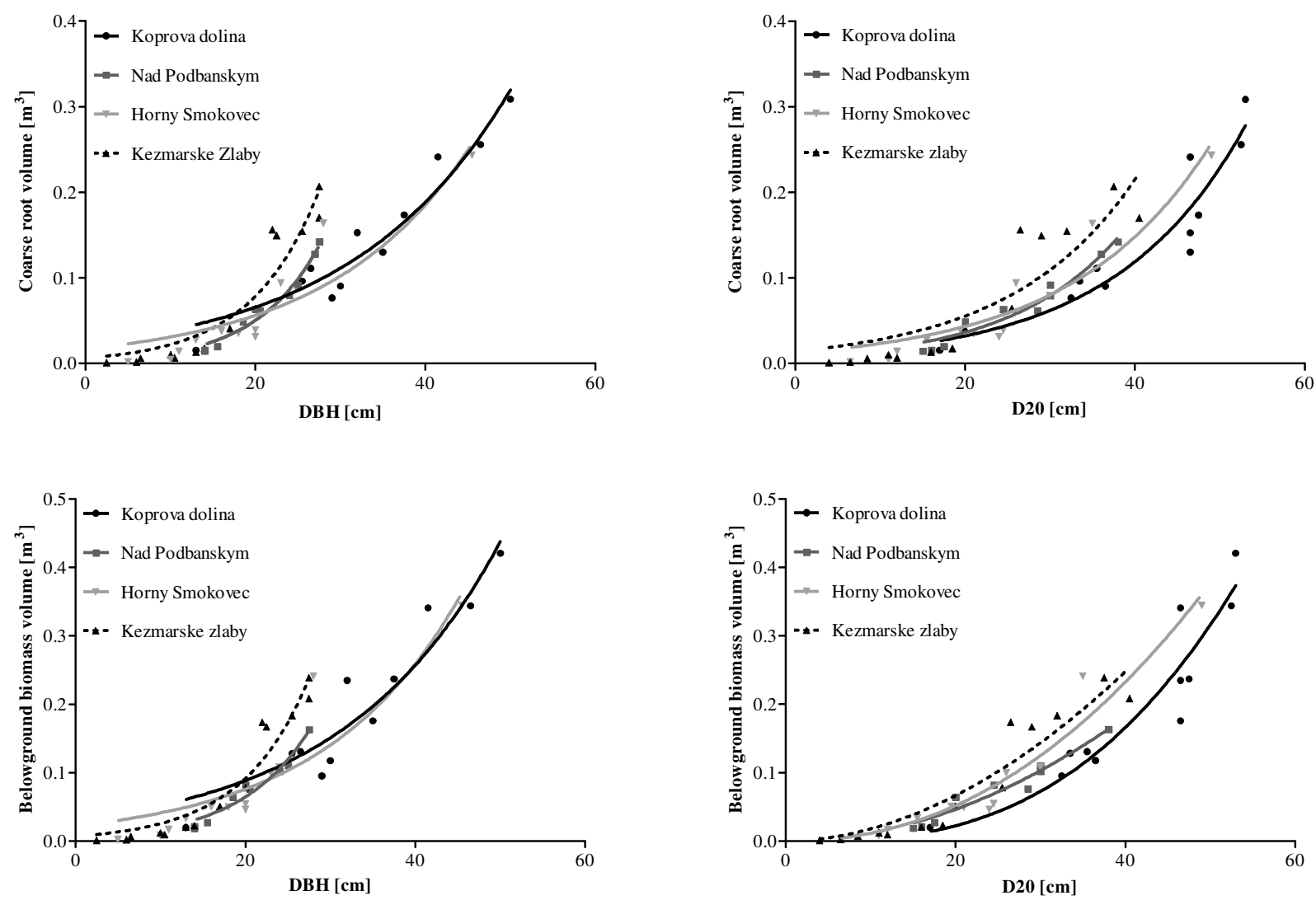


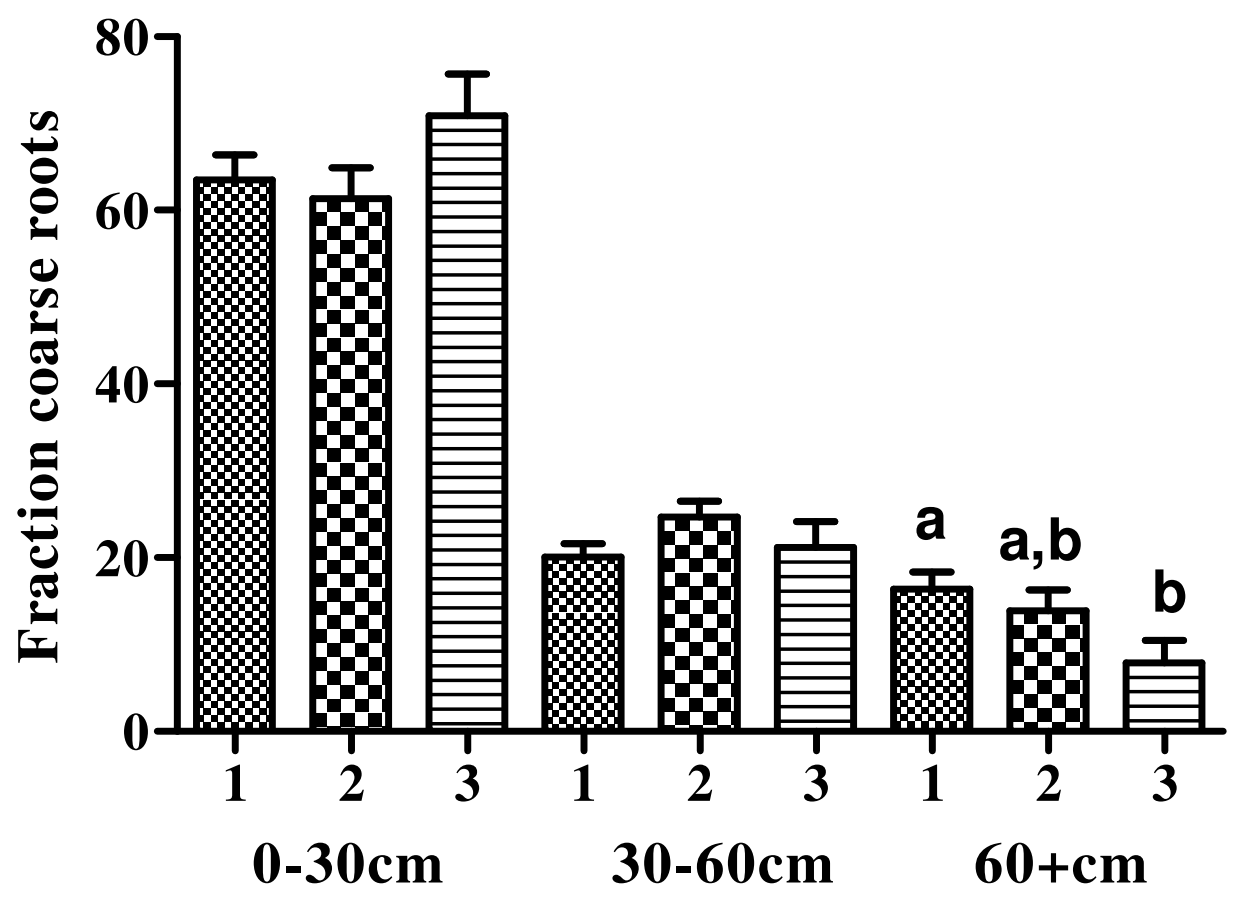




\section{Authors' addresses:}

\section{B. Konopka and J. Pajtik}

\section{NÁRODNÉ LESNÍCKE CENTRUM}

T. G. Masaryka 22

96092 Zvolen

Slovakia

Tel.: +42145 5320316

Fax: +421455314192

M. Lukac

NERC Centre for Population Biology

Division of Biology

Imperial College London

Silwood Park Campus

Ascot

SL5 7PY

UK

Tel. +44 2075942482

Fax +44 1344873173 